
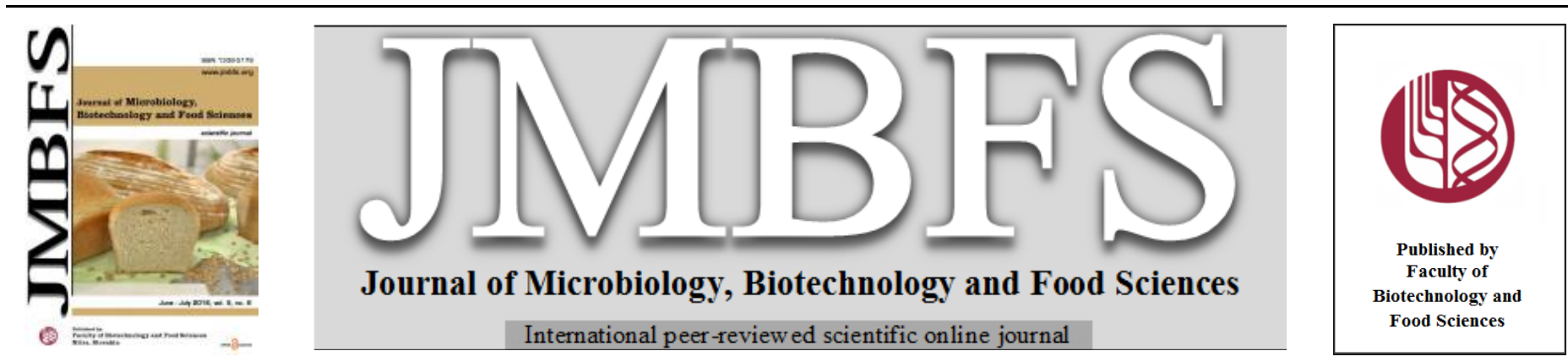

\title{
EVALUATION OF INHIBITORY MEASURES FOR FOOD SPOILER YEAST CANDIDA KRUSEI DURING FERMENTATION PROCESS BY CHEMICAL, BIOCHEMICAL AND NANOPARTICLE APPROACHES
}

\author{
Indrani Bhattacharya, ${ }^{1}$ Jyothi Bezawada, ${ }^{1}$ Jay Shankar Singh Yadav, ${ }^{1}$ Song Yan, ${ }^{1}$ R. D. Tyagi, ${ }^{* 1}$ and R.Y. Surampalli ${ }^{2}$
}

Address(es): R.D.Tyagi,

${ }^{1}$ Institut national de la recherche scientifique, 490, Rue de la Couronne, Québec, Canada G1K 9A9.

${ }^{2}$ Department of Civil Engineering, University of Nebraska-Lincoln, PO Box 886105 Lincoln, USA.

*Corresponding author: Rd.tyagi@ete.inrs.ca

doi: $10.15414 / j m b f s .2016 .5 .6 .509-517$

\section{ARTICLE INFO}

Received 17. 2. 2015

Revised 7. 1. 2016

Accepted 13. 1. 2016

Published 1. 6. 2016

Regular article

OPEN OACCESS

\begin{abstract}
Screening of chemical, biochemical and biomolecule-nanoparticle methods for the inhibition of Candida krusei were evaluated without hampering the growth of dairy yeast Kluyveromyces marxianus. The effective inhibition was observed with the help of $\mathrm{H}_{2} \mathrm{O}_{2}$, Williopsis saturnus, at specific combination of $\mathrm{pH}$ and temperature $\left(\mathrm{pH} 5.0\right.$ and $40{ }^{\circ} \mathrm{C}$ ) and $\mathrm{Ag}-\mathrm{KT} 4561$ nanoparticles among the various methods used. However, the most efficient inhibition was observed with Ag-KT4561 nanoparticles. In general $\mathrm{H}_{2} \mathrm{O}_{2}$ works best at pH range 4.0 to 10.0 and at temperature $30{ }^{\circ} \mathrm{C}$ or above. $\mathrm{H}_{2} \mathrm{O}_{2}$ concentration of $4000 \mathrm{ppm}$ at $45{ }^{\circ} \mathrm{C}$ and pH 5.5 exhibited significant inhibition of $C$. krusei, while $K$. marxianus remains unaffected. But, when used with lyophilized supernatant of W. saturnus, $2400 \mathrm{ppm}^{\mathrm{H}_{2} \mathrm{O}_{2}}$ was effective. Further, nanoparticle with silver was synthesized to reduce the quantity of killer protein and enhance the efficiency of protein. Complete inhibition of $C$. krusei was observed at $350 \mu \mathrm{M}$ of synthesized silver nano-particle (AgNPs) of the killer protein from $W$. saturnus, with little effect on $K$. marxianus concentration. A stability test confirms the effect of protein silver nanoparticles on $C$. krusei for more than 20 weeks without any change in $\mathrm{pH}$ and temperature. Thus, the nanoparticles could be potentially used for inhibition of $C$. kruse $i$ without affecting the growth of $K$. marxianus and the process could be run non-aseptically.
\end{abstract}

Keywords: $\mathrm{H}_{2} \mathrm{O}_{2}$, Spoiler yeast, Inhibition, Killer protein, Ag-KT4561 bio-molecule nanoparticles, Green chemistry

\section{INTRODUCTION}

Cheese whey (a byproduct of cheese processing industries) has been efficiently exploited for the production of single cell protein (SCP) over the years as cheese whey has an immense nutritional value (Ayoola et al., 2008; Carvalho et al., 2013). It contains $4.5-5 \%(\mathrm{w} / \mathrm{v})$ of lactose, $0.6-0.8 \%(\mathrm{w} / \mathrm{v})$ of soluble proteins, $0.4-0.5 \%(\mathrm{w} / \mathrm{v})$ of lipids and $8-10 \%(\mathrm{w} / \mathrm{v})$ of mineral salts of the dried extract. Efficient utilization of cheese whey for SCP conversion reduces the biochemical oxygen demand (BOD) by $75 \%$ and thus decreases the disposal problem (Eyster, 1950; Prazeres et al., 2012). Mostly lactose-consuming organisms, such as Kluyveroymyces spp. and Lactobacillus spp. grow in cheese whey (Koleva et al., 2008; Orru et al., 2010). Production of SCP from cheese whey serves dual purpose by reducing environmental pollution and generating a valuable product (i.e. proteinaceous biomass which is used as animal feed and food ingredients) (Koleva et al., 2008). Likewise, Kluyveroymyces marxianus has been grown in cheese whey as a mono-culture for SCP production (Yadav et al., 2012). However, on a large scale industrial process, contamination is a major problem for SCP production despite the treatment of large volume of cheese whey. To eliminate this problem, certain extreme fermentation parameters have been applied, such as low $\mathrm{pH}(3.0-4.0)$ and high temperature $\left(40-45^{\circ} \mathrm{C}\right)$. At these conditions, most of the pathogenic microorganisms cannot survive (Maneesri and Maneesri, 2009; Ahariz et al., 2010) and therefore a safe food or feed product is ensured during fermentation process. Additionally, the extreme fermentation conditions help to make the process economical due to reduced operating cost of maintaining sterility.

However, certain food spoilers (contaminant) e.g. Candida krusei still survive under extreme conditions ( $\mathrm{pH} 3.0$ and $45^{\circ} \mathrm{C}$ ) (Guo and Bhattacharjee, 2006). The opportunistic Candida species exist as commensal in healthy individuals (Heard and Fleet, 1988). During the production of SCP, C. krusei emerges as a contaminant while it grows along with $K$. marxianus and this is a concern for food safety. C. krusei is known as a food contaminant and an opportunistic pathogen (Siso, 1996; Hornbak et al., 2006; Maneesri and Maneesri, 2007; Kim and Lee, 2012). However, C. krusei is reported to be present in many dairy and fermented food products, but yet does not come under generally recognized as safe (GRAS) microorganism (Walker and Dijck, 2006; Walker et al., 2008).
Therefore, the eradication of $C$. krusei is essential from food products to meet safety regulations.

Certain chemical and biochemical approaches were reported to employ for selective inhibition of $C$. krusei. The chemical $\left(\mathrm{NaCl}, \mathrm{H}_{2} \mathrm{O}_{2}\right)$ and the biological inhibitors (medicinal plants, such as Lupinus angustifolis, Syzigium aromaticum (clove) oil; nisin and Williopsis saturnus and synergistic effect of W. saturnus and $\mathrm{H}_{2} \mathrm{O}_{2}$ ) to inhibit $C$. krusei have been reported (Ayoola et al., 2008; Dingman, 2008; Adeniyi et al., 2010; Da Silva et al., 2011). It was reported that $\mathrm{H}_{2} \mathrm{O}_{2}$ inhibited C. krusei (Morgulis et al., 1926). Apparently, C. krusei has also been tested against a wide range of essential oils where ethanol $70 \% \mathrm{v} / \mathrm{v}$ served as control (Nel et al., 2006; Souza et al., 2008; Waema et al., 2009). Another significant approach to inhibit $C$. krusei was using $\mathrm{NaCl}$; however it depends on the sensitivity of the organism and the concentration of $\mathrm{NaCl}$ used. The sensitive strain of $C$. krusei undergoes cell death at $2 \mathrm{M}$ concentration of $\mathrm{NaCl}$ (Aguiar and Lucas, 2000).

Yeasts such as Aspergillus furnigatus, W. saturnus (major yeast from yogurt) have the capacity to produce killer proteins (Fang et al., 2002; Brock, 2008). The mycotoxins/killer proteins produced by $W$. saturnus have a broad spectrum of inhibitory activity at wide range of $\mathrm{pH}$ and temperature (Buzzini et al., 2004). These could be used as the versatile anti-spoilage agents for food and feed production (Kao et al., 1999; Liu et al., 2006). Another killer protein is nisin, which is used for food preservation and is produced by Lactobacillus spp. or lactic acid bacteria (LAB) (Guwy et al., 1999). Nisin is used to stabilize food products and is often added to the cheese for inhibiting toxin production by Clostridium botulinum. It was also reported to inhibit C. krusei efficiently (Lowes et al., 2000; Russell and Jarvis, 2001).

In certain industrial fermentation processes, stress of $\mathrm{pH}$ shock was encountered to inhibit certain food spoiler yeasts (Siso, 1996; Pinheiro et al., 2002). At pH 2.0, C. krusei did not grow well (Lowes et al., 2000). In a mixed culture, where the presence of other yeast strains was also reported, effective utilization of any inhibitor (i.e. chemical or biochemical inhibitor against C. krusei) depends entirely upon whether the other type of yeast was also inhibited by the specific inhibitor being used. Another effective way of inhibition of pathogens is by the usage of metal nanoparticles (NPs) or biomolecule based nanoparticles (Dingman, 2008). It has already been observed that silver NPs can kill pathogens 
at very low concentrations and biomolecule based nanoparticles do not exert any toxic effects on human cells. Apart from that, silver NPs do not cause any microbial resistance and also there is no specific site of action for inhibition of the microbial cells (Panacek et al., 2009). Hence, the aim of the present study was to evaluate different inhibition methods to inhibit $C$. krusei alone as well as in a mixed culture system without affecting the growth of $K$. marxianus.

\section{MATERIALS AND METHODS}

\section{Chemicals}

Analytical grade chemicals were used in the experiments. $\mathrm{NaCl}$ (Quelab Lab Inc., Montréal, Canada), $\mathrm{H}_{2} \mathrm{O}_{2}$ (Laboratoire Mat, Québec), yeast Extract (Fisher Scientific, USA), malt extract (Oxoid Ltd., Basingstoke, England), meat peptone (Organotechnie SA., La Courneuve, France), glucose, ethyl alcohol 95\% (Fisher Scientific, USA), agar (Quebact Lab Inc., Montréal, Canada), cheese whey (Agropur, Canada), and $\mathrm{AgNO}_{3}$ (Fisher Scientific, Ottawa)

\section{Microorganisms}

K. marxianus strain used in the study was isolated and characterized from the SCP production plant using cheese whey as substrate. C. krusei strain was also isolated and identified as a contaminant during SCP production employing cheese whey. W. saturnus strain DBVPG 4561 was obtained from the Industrial Yeast Collection DBVPG of Perugia (Italy). Strains were sub-cultured on YEPD (yeast extract $10 \mathrm{~g} / \mathrm{L}$, peptone $10 \mathrm{~g} / \mathrm{L}$, dextrose $20 \mathrm{~g} / \mathrm{L}$ ) agar slants and stored at $4{ }^{\circ} \mathrm{C}$ for further use.

\section{Inhibition studies for $C$. kruse}

\section{Chemical Methods}

\section{Inhibition by $\mathrm{NaCl}$}

Pre-culture broth of K. marxianus of $2.0 \times 10^{8} \mathrm{CFU} / \mathrm{mL}$ and C. krusei of $4.0 \times 10$ $\mathrm{CFU} / \mathrm{mL}$ were prepared in $100 \mathrm{~mL}$ YEPD media in $500 \mathrm{~mL}$ Erlenmeyer flasks. The medium $\mathrm{pH}$ was adjusted to 3.5 and sterilized at $121{ }^{\circ} \mathrm{C}$ for $15 \mathrm{~min}$. After sterilization, $1.5 \mathrm{M}$ and $2 \mathrm{M} \mathrm{NaCl}$ were added in different sets of flasks. C. kruse is a non-lactose assimilating organism, while $K$. marxianus is a lactose assimilating organism. Therefore, sterilized YEPD media were inoculated with $30 \mu \mathrm{L}$ (from stock culture) of $K$. marxianus and $50 \mu \mathrm{L}$ of $C$. krusei. Inoculated flasks were incubated at $40{ }^{\circ} \mathrm{C}$ for $24 \mathrm{~h}$. Samples were taken at regular intervals for the analysis of total cell count. Total cell concentration was measured using standard agar plate technique (Logothetis et al., 2007; Goretti et al., 2009; Kosseva et al., 2009).

\section{Inhibition by $\mathrm{H}_{2} \mathrm{O}_{2}$}

A pre-culture was prepared for $C$. krusei and K. marxianus as above. After that, culture media of cheese whey powder $4.5 \%(\mathrm{w} / \mathrm{v})$ and urea $0.22 \%(\mathrm{w} / \mathrm{v})$ were prepared and pasteurized at $80{ }^{\circ} \mathrm{C}$ for $20 \mathrm{~min}$. The pasteurized cheese whey culture media at different $\mathrm{pH}(3.5,4.5,5.5$, and 6.0$)$ was added to different 500 $\mathrm{mL}$ flasks and inoculated with $1 \%(\mathrm{v} / \mathrm{v})$ inoculum of $C$. krusei and $K$. marxianus. Different concentrations of $\mathrm{H}_{2} \mathrm{O}_{2}(100,200,300$ and $400 \mathrm{ppm})$ were added to these flasks. After inoculation, flasks were incubated at $28{ }^{\circ} \mathrm{C}$ and $40{ }^{\circ} \mathrm{C}$ in an orbital incubator shaker for $24 \mathrm{~h}$. Samples were drawn at regular intervals to analyze the total cell count.

Simultaneously, two different set of experiments were conducted, where in the primary set of experiments the $\mathrm{H}_{2} \mathrm{O}_{2}$ concentration were varied $(0,300,400,500$, 600 and $800 \mathrm{ppm}$ ) and applied directly on the fermenter broth containing $K$. marxianus and $C$. krusei, which was collected from commercial continuous SCP production plant. $100 \mathrm{~mL}$ of fermented broth of $K$. marxinaus $\left(3.0 \times 10^{6} \mathrm{CFU} / \mathrm{mL}\right)$ severely contaminated with $C$. krusei $\left(1.8 \times 10^{6} \mathrm{CFU} / \mathrm{mL}\right)$ was taken in $500 \mathrm{~mL} 2$ sterilized flasks. Flasks were incubated at $\mathrm{pH} 3.5,150 \mathrm{rpm}$ and $40{ }^{\circ} \mathrm{C}$ in an incubator shaker.

In the secondary set of experiments, variation in $\mathrm{H}_{2} \mathrm{O}_{2}$ concentration $(2400,3200$ and $4000 \mathrm{ppm}$ ) were considered and applied directly to the fermenter broth and flasks were incubated at $\mathrm{pH} 5.0,150 \mathrm{rpm}$ and $45^{\circ} \mathrm{C}$ in an incubator shaker.

\section{Biochemical Methods}

\section{Inhibition by S. aromaticum oil}

A set of experiments were conducted in which $0.4 \%(\mathrm{v} / \mathrm{v})$ of clove oil was added in fermenter broth which contains $C$. krusei and $K$. marxianus. The initial cell count of $C$. krusei and $K$. marxianus was $5.0 \times 10^{6} \mathrm{CFU} / \mathrm{mL}$ and $6.0 \times 10^{6} \mathrm{CFU} / \mathrm{mL}$, respectively. The flasks were placed in an orbital incubator shaker at $28^{\circ} \mathrm{C}$ at 150 $\mathrm{rpm}$ for $6 \mathrm{~h}$. Sampling was performed at an interval of $2 \mathrm{~h}$. Samples were analyzed for total cell count using standard agar plate technique.

\section{Inhibition with nisin}

The culture of $C$. krusei and $K$. marxianus were grown separately in MRS broth at $35{ }^{\circ} \mathrm{C}$ for $24 \mathrm{~h}$. Bioassay MRS media with $0.75 \%$ of Bacto agar and $1 \%$ Tween-20 were prepared. Media were sterilized at $121^{\circ} \mathrm{C}$ for $15 \mathrm{~min}$. A solution of nisin $(1,000 \mathrm{IU} / \mathrm{mL})$ was prepared by adding $0.025 \mathrm{~g}$ of commercial nisin (Sigma-Aldrich, Milwaukee, USA) into $25 \mathrm{ml}$ of sterile solution of $0.02 \mathrm{~N} \mathrm{HCl}$ Sterilized media were cooled down to $40{ }^{\circ} \mathrm{C}$ and inoculated with $1 \%(\mathrm{v} / \mathrm{v})$ of the $24 \mathrm{~h}$ culture of $C$. krusei and K. marxianus in two sets (duplicate). Then the bioassay agar $(25 \mathrm{~mL})$ was aseptically poured into sterile petri dishes $(100 \mathrm{x} 15$ $\mathrm{mm}$ ) and allowed to solidify for $1 \mathrm{~h}$. On each plate, four or five holes were bored, using a $7 \mathrm{~mm}$ outer diameter stainless steel borer with a slight suction. An aliquot (50 $\mu \mathrm{L}$ and $100 \mu \mathrm{L}$ ) of standard nisin solution was placed into a well and the bioassay agar plate was incubated right away at $35{ }^{\circ} \mathrm{C}$ for $24 \mathrm{~h}$. The control for each plate was prepared using sterile distilled water in wells. Zone of inhibition was observed in control and test samples.

\section{Inhibition study with $W$. saturnus}

\section{Preparation of W. saturnus culture broth}

YEPD $(100 \mathrm{~mL})$ was prepared in $500 \mathrm{~mL}$ flasks and sterilized at $121{ }^{\circ} \mathrm{C}$ for 15 min. The sterilized flask was inoculated with loopful of $W$. saturnus and incubated in an orbital incubator shaker at $150 \mathrm{rpm}$ and $28{ }^{\circ} \mathrm{C}$ for $48 \mathrm{~h}$. Samples were taken at regular time intervals for total cell count.

\section{Well assay method}

Pre-culture of $C$. krusei was prepared in YEPD as described above using $1 \%$ (v/v) inoculum. After $24 \mathrm{~h}, \mathrm{C}$. krusei sample was diluted $10^{2}, 10^{3}$ and $10^{4}$ times in saline solution and different diluted samples were spread plated in YEPD agar plates. After spread plating, wells were made in agar plates using borer and 60 $\mu \mathrm{L}$ of $W$. saturnus $(48 \mathrm{~h})$ culture was added in each well. The plates were incubated in an orbital incubator at $28{ }^{\circ} \mathrm{C}$ for $24 \mathrm{~h}$. The plates were visually observed after $24 \mathrm{~h}$.

To differentiate the morphology of $C$. krusei from W. saturnus, Methylene Blue Citric-Phosphate agar (MBA) plates were prepared and spread plated using $C$. krusei and W. saturnus. Plates were incubated for $24 \mathrm{~h}$ at $28^{\circ} \mathrm{C}$ and were visually examined to check the morphology.

\section{Inhibition by W. saturnus}

W. saturnus was grown in YEPD and cheese whey medium for $24 \mathrm{~h}$. YEPD and cheese whey powder $4.5 \%(\mathrm{w} / \mathrm{v})$ with $0.22 \%(\mathrm{w} / \mathrm{v})$ urea were prepared in two flasks of $2 \mathrm{~L}$ capacity each containing $500 \mathrm{~mL}$ medium. After sterilization, each flask was inoculated with $2 \%(\mathrm{v} / \mathrm{v}) W$. saturnus and incubated in an orbital incubator shaker at $150 \mathrm{rpm}$ and $28{ }^{\circ} \mathrm{C}$. The culture was harvested at $48 \mathrm{~h}$. The culture broth was centrifuged at $10000 \mathrm{x} \mathrm{g}$ and the supernatant was lyophilized to obtain the powder which contained extracellular proteins. The extracellular proteins specifically contain a particular protein KT4561 ( 62 kDa protein), which has anti-mycotic activity (Buzzini et al., 2004). Simultaneously, another set of flasks containing W. saturnus were grown, where no centrifugation was performed. Henceforth, the cultures were directly taken for lyophilization.

Pre-cultures were prepared by growing $C$. krusei, $K$. marxianus and W. saturnus in YEPD medium for $24 \mathrm{~h}$. One hundred milliliters of fresh cheese whey powder $4.5 \%(\mathrm{w} / \mathrm{v})$ with urea $0.22 \%(\mathrm{w} / \mathrm{v})$ solution was added to each five hundred milliliters Erlenmeyer flask (two flasks) and pasteurized at $80{ }^{\circ} \mathrm{C}$ for $20 \mathrm{~min}$ After pasteurization, media were aseptically adjusted to different $\mathrm{pH}$ (3.5 and 4.5) followed by inoculation with $1 \%(\mathrm{v} / \mathrm{v})$ mixed culture (C. krusei and $K$. marxianus)

\section{Inhibition by lyophilized supernatant from $W$. saturnus}

Various concentrations of lyophilized supernatant of W. saturnus were considered (well plate assay method) and the zone was created by the inhibitory effect of the killer protein. The inhibition zones were measured after $24 \mathrm{~h}$ of incubation at $30{ }^{\circ} \mathrm{C}$. A linear equation $(\mathrm{y}=0.30 \mathrm{x}-0.36)$ was sketched out between the diameter of the clear zone (measured in millimeters, $\mathrm{x}$ axis) and the logarithm of the quantity of the killer protein (measured in nanograms, y axis). This method was used to determine the killer protein concentration required for the inhibition of $C$. kruse $i$ which is similar to the technique mentioned in (Chen et al., 2000). Lyophilized supernatant prepared in YEPD media was served as the control and lyophilized cheese whey was the experimental product.

\section{Inhibition of C. krusei by synergistic effect of $\mathrm{H}_{2} \mathrm{O}_{2}$ and W. saturnus}

To study inhibition of $C$. krusei, different $\mathrm{H}_{2} \mathrm{O}_{2}$ concentrations were used along with $W$. saturnus (entire organism lyophilized supernatant powder, as described 
above). $300 \mathrm{ppm}$ of $\mathrm{H}_{2} \mathrm{O}_{2}$ was used along with $1 \%(\mathrm{v} / \mathrm{v})$ of $W$. saturnus (inoculum from pre-culture) for the inhibition of $\mathrm{C}$. krusei in a mixed culture of C. kruse $i$ and $K$. marxianus at $\mathrm{pH} 6.0$ and $28^{\circ} \mathrm{C}$. Similar sets of experiments were conducted with a variation in $\mathrm{pH}(3.5-4.5)$ at $28^{\circ} \mathrm{C}$.

Two different set of experiments were conducted, where in the primary set of experiments was conducted where lyophilized W. saturnus was used by varying the $\mathrm{H}_{2} \mathrm{O}_{2}$ concentration directly on the fermenter broth containing $K$. marxianus and $C$. krusei, collected from commercial continuous SCP production plant. 100 $\mathrm{mL}$ of fermented broth of $K$. marxinaus $\left(3.1 \times 10^{6} \mathrm{CFU} / \mathrm{mL}\right)$ grossly contaminated with $C$. krusei $\left(1.5 \times 10^{6} \mathrm{CFU} / \mathrm{mL}\right)$ was taken in $500 \mathrm{~mL} 2$ sterilized flasks. The lyophilized powder of $W$. saturnus $(200 \mathrm{mg} / \mathrm{mL})$ along with different concentrations of $\mathrm{H}_{2} \mathrm{O}_{2}(2400$ and $4000 \mathrm{ppm})$ was then added to each flask. Flasks were incubated at $\mathrm{pH} 5.0,150 \mathrm{rpm}$ and $40{ }^{\circ} \mathrm{C}$ in an incubator shaker. supernatant of $W$. saturnus was used along with $2400 \mathrm{ppm}$ of $\mathrm{H}_{2} \mathrm{O}_{2}$ in a mixed culture by adjusting the $\mathrm{pH}$ of fermenter broth to 5.0. As the killer protein produced by lyophilized $W$. saturnus is highly effective at $\mathrm{pH}$ range of 4.5-10.0 and temperature from 25 to $45{ }^{\circ} \mathrm{C}$ (Goretti et al., 2009). Flasks were kept at 150 $\mathrm{rpm}$ and $40^{\circ} \mathrm{C}$ in an orbital incubator shaker.

\section{Inhibition of C. krusei by Ag-KT4561 NPs}

Synthesis of nanoparticles (Ag-KT4561) was carried out in the previous study (Bhattacharya et al., 2015). However a bulk preparation of the same has been conducted in this study. During the scale-up process, $20 \mathrm{~mL}$ of $0.1 \mathrm{M} \mathrm{AgNO}_{3}$ solution is continuously stirred along with $18 \mathrm{~mL}$ of $W$. saturnus supernatant at $25^{\circ} \mathrm{C}$ for $48 \mathrm{~h} . \mathrm{Ag}^{+}$ions were completely reduced at $48 \mathrm{~h}$ of stirring. After which the bulk nanoparticle solution was taken for lyophilization and the lyophilized product was tried against C. krusei in $4.5 \%(\mathrm{w} / \mathrm{v})$ cheese whey and $0.22 \%(\mathrm{w} / \mathrm{v})$ of urea. From the lyophilized product different concentration of Ag-KT4561 ranging from $10 \mu \mathrm{M}-1 \mathrm{mM}$ were tried at $\mathrm{pH} 5.5$ and $30^{\circ} \mathrm{C}$ in shake flasks. In these experiments, mixed culture of $C$. krusei $(2 \%$ (v/v)) and $K$. marxianus $(2 \%$ $(\mathrm{v} / \mathrm{v}))$ were tested for $12 \mathrm{~h}$ and total cell concentration $(\mathrm{CFU} / \mathrm{mL})$ was measured at $3 \mathrm{~h}$ time intervals.
Whereas in secondary set of experiments, about $400 \mathrm{mg} / \mathrm{mL}$ of lyophilized

\section{Analytical methods}

\section{Cell count}

Total cell count as CFU (colony forming units) was estimated by standard agar plate technique in YEPD agar plates (Nathan et al., 1978). The appropriately diluted samples were plated on agar plates and incubated at $30{ }^{\circ} \mathrm{C}$ overnight to form fully developed colonies. The colonies of $K$. marxianus, C. krusei and $W$. saturnus were identified based on its morphology by visible examination.

\section{Protein estimation}

The soluble protein concentration was determined by Lowry's method (Lowry et al., 1951) using bovine serum albumin as standard.

\section{UV-Vis Spectroscopy}

The bulk sample of $\mathrm{AgNO}_{3}$ and W. saturnus supernatant were prepared at $48 \mathrm{~h}$ and samples were collected at every $6 \mathrm{~h}$ to analyze for nanoparticle formation at 300-700 nm in Spectrophotometer (Carry 100 Bio ${ }^{\circledR}$, Varian USA).

\section{Statistical method}

For each set, samples were analyzed in triplicates and mean values are taken in account. Further standard deviation of the colonies in $\log$ units $\left(\log _{10} \mathrm{CFU} / \mathrm{mL}\right.$ ) were calculated for each experimental point in Microsoft excel 2013 externa package similar to the method of De Oliveira et al., 2014.

\section{RESULTS}

\section{Inhibition by $\mathrm{NaCl}$}

Different concentrations (1.5- $2 \mathrm{M}$ ) of $\mathrm{NaCl}$ were tested to inhibit the growth of C. krusei in mono-culture and the results were presented in Figure 1. It was clear that $\mathrm{NaCl}$ concentration of $2 \mathrm{M}$ showed significant inhibition of $C$. kruse compared to $1.5 \mathrm{M}$ without having any effect on $K$. maxianus. This is due to the fact that $C$. krusei exhibited salt-stress (Aguiar and Lucas, 2000) and got killed at $\mathrm{pH} 3.5$ and $40{ }^{\circ} \mathrm{C}$. No inhibition of C. krusei was observed when $\mathrm{NaCl}$ concentration was less than $2 \mathrm{M}$ at $\mathrm{pH} 3.5$ and $40{ }^{\circ} \mathrm{C}$.
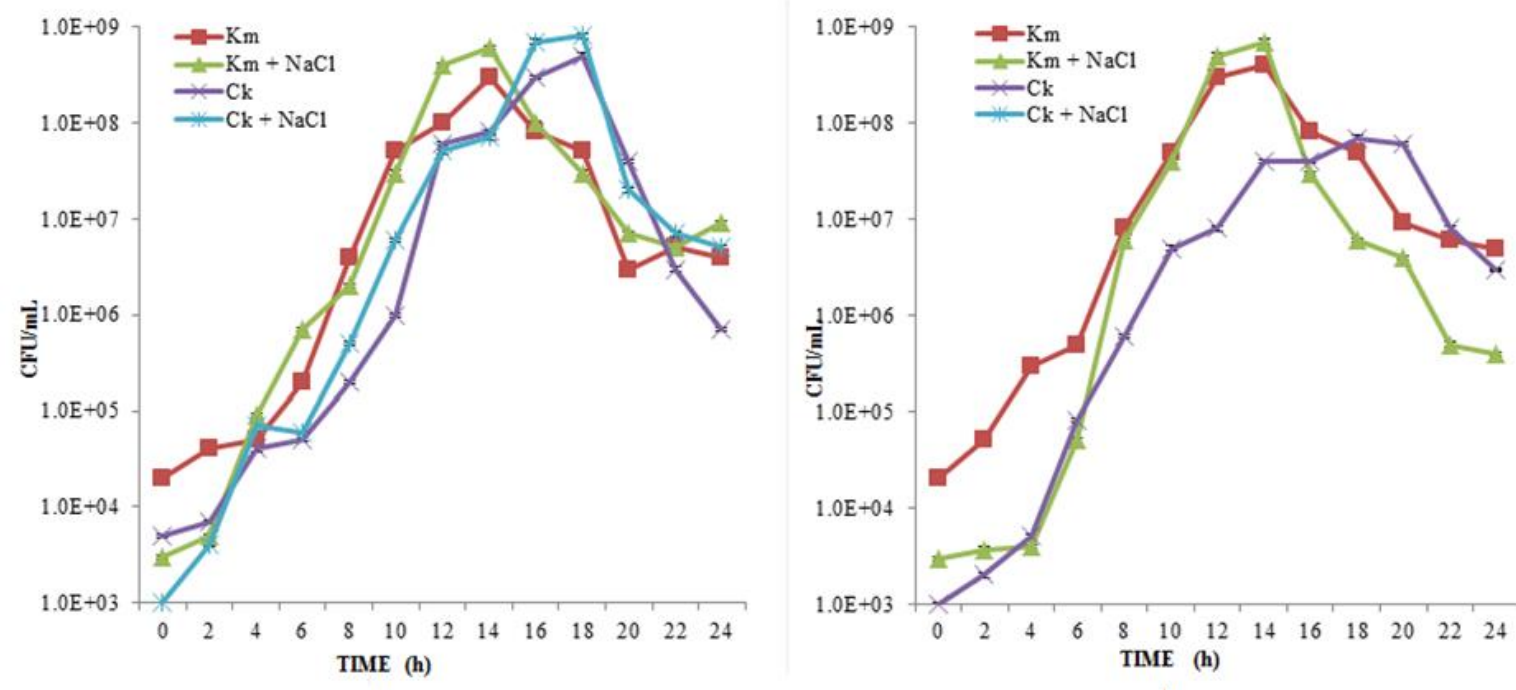

b

Figure 1 Impact of a) $1.5 \mathrm{M} \mathrm{NaCl}$ and b) $2.0 \mathrm{M}$ on C. krusei $(\mathrm{Ck})$ and $K$. marxinaus $(\mathrm{Km})$ in YEPD medium at $\mathrm{pH} 3.5$ and $40{ }^{\circ} \mathrm{C}$ (Shake flask experiments)

\section{Inhibition by $\mathrm{H}_{2} \mathrm{O}_{2}$}

Viability of individual cultures of $C$. krusei, and $K$. marxianus at different concentrations of $\mathrm{H}_{2} \mathrm{O}_{2}(100-400 \mathrm{ppm})$ in cheese whey at $\mathrm{pH} 6.0$ and $28^{\circ} \mathrm{C}$ was studied (Table 1). It showed that C. krusei was not inhibited at lower concentration of $\mathrm{H}_{2} \mathrm{O}_{2}$. However, inhibition occurred at 300 ppm $\mathrm{H}_{2} \mathrm{O}_{2}$. $K$ marxianus was not inhibited at these concentrations of $\mathrm{H}_{2} \mathrm{O}_{2}$. 
Table 1 Impact of various concentrations of $\mathrm{H}_{2} \mathrm{O}_{2}$ on C. krusei and K. marxianus in cheese whey powder at $\mathrm{pH} 6.0$ and temperature $28^{\circ} \mathrm{C}$ (Shake flask)

\begin{tabular}{lccccccc}
\hline \multicolumn{7}{c}{ Individual Organisms $\left(\log _{10} \mathbf{C F U} / \mathbf{m L}\right) \pm$ Standard Deviation } \\
\hline $\begin{array}{l}\mathbf{H}_{\mathbf{2}} \mathbf{O}_{\mathbf{2}} \\
\mathbf{p p m})\end{array}$ & $\mathbf{0}$ & & $\mathbf{1 0 0}$ & $\mathbf{2 0 0}$ & $\mathbf{3 0 0}$ & $\mathbf{4 0 0}$ & \\
\hline $\begin{array}{l}\text { Time } \\
\text { (h) }\end{array}$ & $\mathbf{C k}$ & $\mathbf{K m}$ & $\mathbf{C k}$ & $\mathbf{C k}$ & $\mathbf{C k}$ & $\mathbf{C k}$ & $\mathbf{K m}$ \\
\hline 0 & $5.73 \pm .07$ & $4.83 \pm .01$ & $5.81 \pm .01$ & $5.81 \pm .01$ & $5.92 \pm .01$ & $5.15 \pm .03$ & $5.81 \pm .02$ \\
\hline 12 & $6.52 \pm .02$ & $9.33 \pm .01$ & $6.08 \pm .03$ & $5.23 \pm .01$ & $5.40 \pm .04$ & NG & $9.26 \pm .02$ \\
\hline 24 & $8.51 \pm .02$ & $8.31 \pm .01$ & $6.12 \pm .05$ & $5.18 \pm .05$ & $\mathrm{NG}$ & $\mathrm{NG}$ & $8.28 \pm .02$ \\
\hline
\end{tabular}

The inhibition of $C$. krusei in mixed cultures (C. krusei and $K$. marxianus) in cheese whey was studied and the results were presented in Figure 2. The concentration of $\mathrm{H}_{2} \mathrm{O}_{2}$ used was $300 \mathrm{ppm}$ and $400 \mathrm{ppm}$ (from previous results in Table 1). C. krusei was not inhibited at $300-400$ ppm of $\mathrm{H}_{2} \mathrm{O}_{2}$. On the contrary, $C$. krusei dominated over $K$. marxianus in a mixed culture at $24 \mathrm{~h}$.

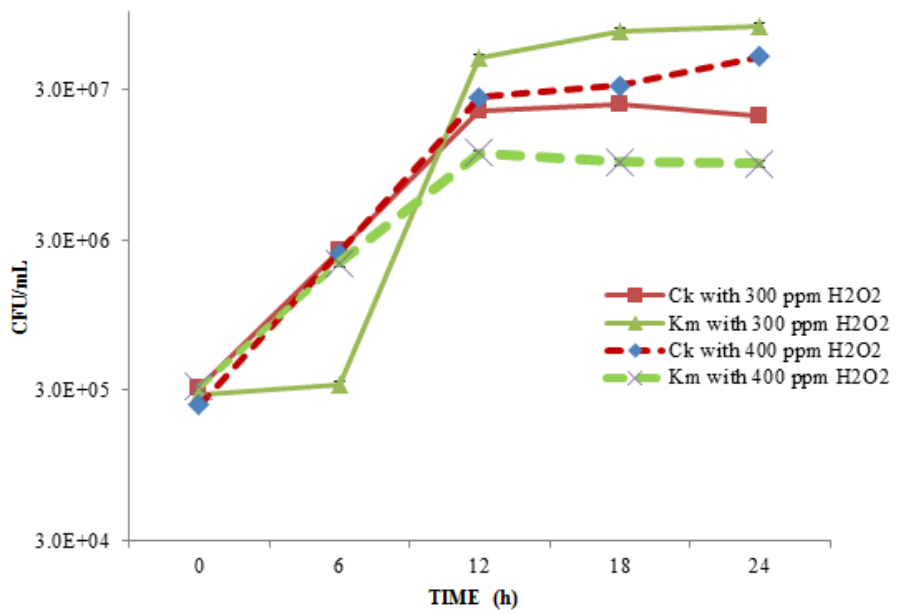

Figure 2 Impact of $\mathrm{H}_{2} \mathrm{O}_{2}$ on $C$. krusei $(\mathrm{Ck}), K$. marxianus $(\mathrm{Km})$ in cheese whey at pH 6.0 and $28^{\circ} \mathrm{C}$ with $300 \mathrm{ppm}$ and $400 \mathrm{ppm} \mathrm{H}_{2} \mathrm{O}_{2}$

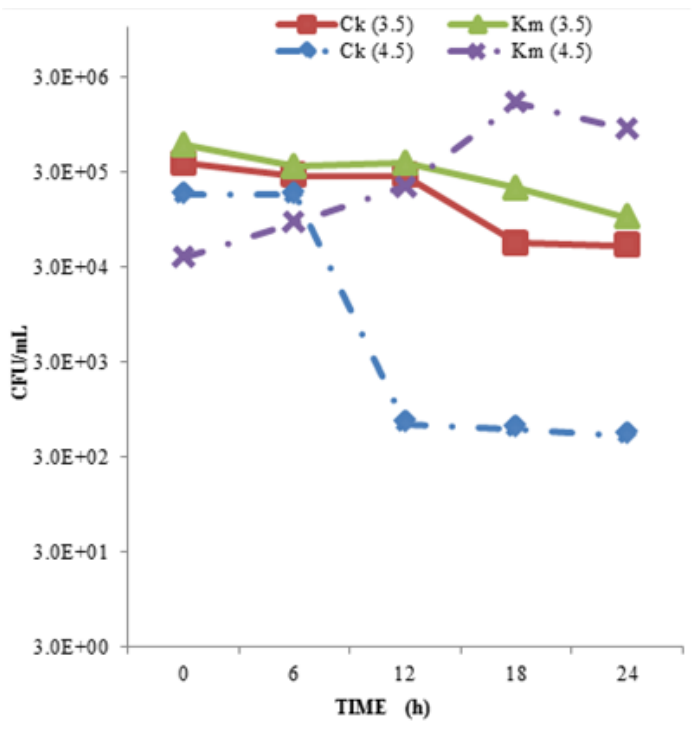

a

Figure 3 Impact of $\mathrm{H}_{2} \mathrm{O}_{2}$ and W. saturnus (Ws) on the mixed culture (C. krusei $(\mathrm{Ck})$ and $K$. marxianus $\left.(\mathrm{Km})\right)$ in cheese whey at pH (3.5, 4.5) and $28{ }^{\circ} \mathrm{C}$ (Shake flask). a) With $300 \mathrm{ppm} \mathrm{H}_{2} \mathrm{O}_{2}$ only b) With $300 \mathrm{ppm}_{2} \mathrm{O}_{2}$ and $1 \%$ (v/v) W. saturnus
C. krusei was efficiently inhibited in mixed cultures (C. krusei and K. marxianus) and (C. krusei, K. marxianus and W. saturnus) at $\mathrm{pH} 4.0,28^{\circ} \mathrm{C}$ and $400 \mathrm{ppm}$ of $\mathrm{H}_{2} \mathrm{O}_{2}$. Lower $\mathrm{CFU} / \mathrm{mL}$ of $1.7 \times 10^{3}$ was observed for $K$. marxianus at $\mathrm{pH} 4.0$ and $28^{\circ} \mathrm{C}$. On the contrary, when $C$. krusei was grown along with $K$. marxianus and W. saturnus, $K$. marxianus was observed at high $\mathrm{CFU} / \mathrm{mL}$ of $2.4 \times 10^{3}$ (as

\section{Variations in $\mathrm{pH}$ along with $300 \mathrm{ppm} \mathrm{H}_{2} \mathrm{O}_{2}$ concentration}

$\mathrm{pH}$ variations were carried out and it was lowered to 3.5 from 6.0 and studies of mixed culture (C. krusei, K. marxianus and W. saturnus $1 \%$ and $2 \%(\mathrm{v} / \mathrm{v}))$ were also carried out maintaining similar parameters in cheese whey. C. krusei was not inhibited at these parameters, whereas growth of $K$. marxianus and $W$. saturnus remains unchanged.

A mixed culture study at $\mathrm{pH} 4.5$ and $28{ }^{\circ} \mathrm{C}$ in cheese whey powder with $300 \mathrm{ppm}$ $\mathrm{H}_{2} \mathrm{O}_{2}$ exhibited a partial inhibition of $C$. krusei (Figure 3a). However when biopreservative $W$. saturnus was added at the similar condition, the growth of $C$. krusei decreased by one log-unit at $12 \mathrm{~h}$ (Figure 3b), but the growth accelerated after $12 \mathrm{~h}$. As W. saturnus produces killer protein (KT4561) but the concentration of the killer protein remains low which is insufficient to inhibit C. krusei in a large-scale fermentation. Hence, this parameter could be considered for the inhibition of $C$. krusei.

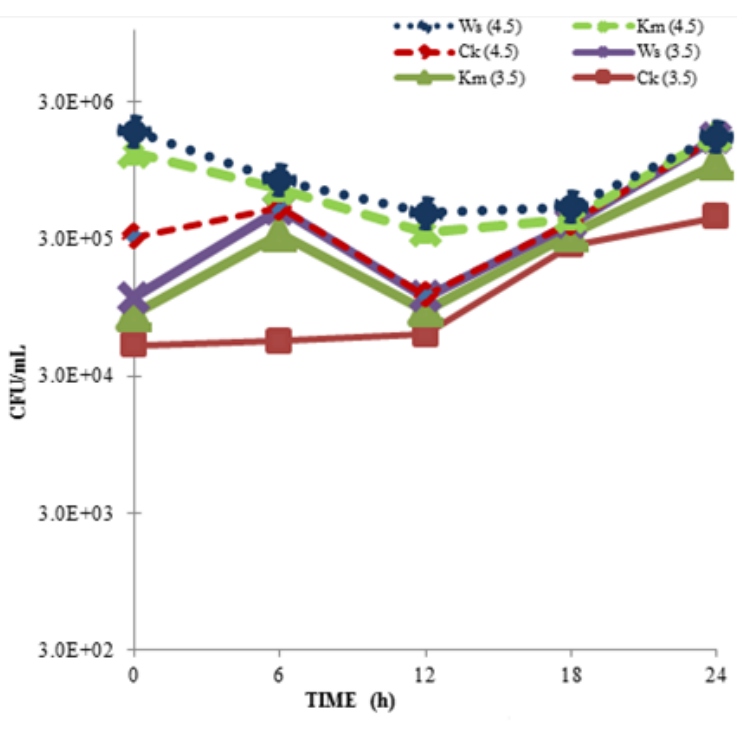

b showed remarkable growth at $\mathrm{pH} 5.5$ and $40{ }^{\circ} \mathrm{C}$ rather than at other $\mathrm{pH}$ values, hence $\mathrm{pH}$ 4.5-5.5 was ideal for K. marxianus. 


\section{Higher ranges of $\mathrm{H}_{2} \mathrm{O}_{2}$ concentrations}

After deducing the optimum amount of $\mathrm{H}_{2} \mathrm{O}_{2}$ used for the complete inhibition of C. krusei, similar concentration was applied for industrial scale fermenter broth to eliminate $C$. krusei without affecting the $K$. marxianus. So, $300 \mathrm{ppm}$ of $\mathrm{H}_{2} \mathrm{O}_{2}$ was the optimum concentration for inhibiting $C$. krusei in the mixed culture in shake flask experiments. When concentration of $\mathrm{H}_{2} \mathrm{O}_{2}$ was increased from 300 to $800 \mathrm{ppm}$ in the lab scale fermenter broth, no significant inhibition of C. krusei was observed at $\mathrm{pH} 3.5$ and $40{ }^{\circ} \mathrm{C}$ (Table 2). K. marxianus degraded $\mathrm{H}_{2} \mathrm{O}_{2}$ at $\mathrm{pH}$ 3.5, making $\mathrm{H}_{2} \mathrm{O}_{2}$ ineffective for $C$. krusei inhibition (Pinheiro et al., 2002). In fermented broth, higher concentration ( $2400 \mathrm{ppm}, 3200 \mathrm{ppm}$, and $4000 \mathrm{ppm}$ ) of $\mathrm{H}_{2} \mathrm{O}_{2}$ was considered at $\mathrm{pH} 5.0$ and $45^{\circ} \mathrm{C}$. Study was conducted for $6 \mathrm{~h}$, as $\mathrm{H}_{2} \mathrm{O}_{2}$ got degraded into $\mathrm{H}_{2} \mathrm{O}$ and $\mathrm{O}_{2}$ after $6 \mathrm{~h}$ (Table 3 ). A very high concentration 4000 ppm of $\mathrm{H}_{2} \mathrm{O}_{2}$ finally could kill $C$. krusei completely in the fermented broth Higher concentration of $\mathrm{H}_{2} \mathrm{O}_{2}$ was required due to simultaneous degradation of $\mathrm{H}_{2} \mathrm{O}_{2}$ by catalase action of $K$. marxianus (Pinheiro et al., 2002).

Table 2 Impact of varying concentration of $\mathrm{H}_{2} \mathrm{O}_{2}$ on the mixed culture in the fermenter broth at pH 3.5 and $40{ }^{\circ} \mathrm{C}(\mathrm{Shake}$ flask)

\begin{tabular}{|c|c|c|c|c|c|c|c|c|c|c|c|c|}
\hline & \multicolumn{12}{|c|}{$\mathrm{H}_{2} \mathrm{O}_{2}(\mathrm{ppm})$} \\
\hline & \multicolumn{2}{|c|}{$\mathbf{0}$} & \multicolumn{2}{|c|}{300} & 400 & \multicolumn{2}{|r|}{500} & \multicolumn{2}{|r|}{600} & \multicolumn{2}{|r|}{800} & \\
\hline & \multicolumn{12}{|c|}{ Individual Organisms $\left(\log _{10} \mathrm{CFU} / \mathrm{mL}\right) \pm$ Standard Deviation } \\
\hline $\begin{array}{l}\text { Time } \\
\text { (h) }\end{array}$ & $\mathbf{C k}$ & Km & $\mathbf{C k}$ & Km & $\mathbf{C k}$ & Km & $\mathbf{C k}$ & Km & $\mathbf{C k}$ & Km & $\mathbf{C k}$ & Km \\
\hline 0 & $7.88 \pm .01$ & $9.04 \pm .02$ & $8.26 \pm .02$ & $8.97 \pm .02$ & $8.42 \pm .02$ & $8.71 \pm .01$ & $7.17 \pm .03$ & $7.67 \pm .01$ & $6.02 \pm .02$ & $6.14 \pm .05$ & $6.17 \pm .11$ & $5.87 \pm .02$ \\
\hline 3 & $7.91 \pm .01$ & $8.89 \pm .01$ & $8.34 \pm .02$ & $8.72 \pm .01$ & $8.12 \pm .02$ & $8.76 \pm .01$ & $6.71 \pm .01$ & $6.15 \pm .05$ & $6.47 \pm .10$ & $6.87 \pm .01$ & $5.34 \pm .03$ & $6.49 \pm .02$ \\
\hline 6 & $8.18 \pm .04$ & $7.05 \pm .01$ & $8.18 \pm .03$ & $8.69 \pm .01$ & $7.96 \pm .01$ & $7.96 \pm .01$ & $6.85 \pm .01$ & $6.11 \pm .03$ & $6.04 \pm .04$ & $6.95 \pm .04$ & $5.36 \pm .04$ & $6.87 \pm .02$ \\
\hline 9 & $7.78 \pm .01$ & $7.79 \pm .01$ & $8.28 \pm .02$ & $8.80 \pm .01$ & $8.18 \pm .03$ & $8.18 \pm .03$ & $6.77 \pm .01$ & $7.28 \pm .03$ & $6.85 \pm .04$ & $7.32 \pm .07$ & $6.04 \pm .02$ & $6.70 \pm .08$ \\
\hline 12 & $7.18 \pm .04$ & $8.12 \pm .06$ & $8.80 \pm .02$ & $8.18 \pm .02$ & $8.32 \pm .02$ & $8.32 \pm .02$ & $6.72 \pm .01$ & $6.90 \pm .01$ & $8.25 \pm .13$ & $8.00 \pm .02$ & $6.47 \pm .03$ & $7.47 \pm .02$ \\
\hline 24 & $8.40 \pm .02$ & $8.08 \pm .09$ & $8.45 \pm .02$ & $8.45 \pm .03$ & $8.42 \pm .02$ & $8.42 \pm .02$ & $8.04 \pm .13$ & $8.04 \pm .02$ & $8.45 \pm .06$ & $7.41 \pm .07$ & $8.41 \pm .05$ & $7.98 \pm .02$ \\
\hline
\end{tabular}

Legend: Ck- C. krusei, $\mathrm{Km}-$ K. marxianus

Table 3 Impact of higher concentrations of $\mathrm{H}_{2} \mathrm{O}_{2}$ on the mixed culture in the fermenter broth at pH 5.0 and $45^{\circ} \mathrm{C}(\mathrm{Shake}$ flask)

\begin{tabular}{|c|c|c|c|c|c|c|}
\hline \multirow[t]{4}{*}{ Time (h) } & \multicolumn{6}{|c|}{$\mathrm{H}_{2} \mathrm{O}_{2}(\mathbf{p p m})$} \\
\hline & \multicolumn{2}{|c|}{2400} & \multicolumn{2}{|c|}{3200} & \multicolumn{2}{|c|}{4000} \\
\hline & \multicolumn{6}{|c|}{ Individual Organisms $\left(\log _{10} \mathrm{CFU} / \mathrm{mL}\right) \pm$ Standard Deviation } \\
\hline & $\mathbf{C k}$ & Km & $\mathbf{C k}$ & Km & $\mathbf{C k}$ & Km \\
\hline 0 & $6.18 \pm .04$ & $6.50 \pm .02$ & $5.31 \pm .02$ & $6.31 \pm .02$ & NG & $5.18 \pm .05$ \\
\hline 2 & $6.31 \pm .01$ & $6.58 \pm .01$ & $6.18 \pm .03$ & $6.42 \pm .01$ & NG & $5.31 \pm .01$ \\
\hline 4 & $6.47 \pm .02$ & $6.57 \pm .01$ & $6.31 \pm .01$ & $6.48 \pm .01$ & $\mathrm{NG}$ & $5.31 \pm .03$ \\
\hline 6 & $6.52 \pm .01$ & $6.81 \pm .01$ & $6.37 \pm .02$ & $6.54 \pm .01$ & $\mathrm{NG}$ & $5.39 \pm .01$ \\
\hline
\end{tabular}

\section{Inhibition by $S$. aromaticum oil}

A study of the mixed culture (C. krusei and $K$. marxianus) at $\mathrm{pH} 3.5$ and $28^{\circ} \mathrm{C}$ along with various concentrations of clove oil was performed. It was observed that using clove oil concentration $0.5 \%(\mathrm{v} / \mathrm{v})$ at $\mathrm{pH} 3.5$ and $28^{\circ} \mathrm{C}$ is ideal for $C$ krusei inhibition without affecting much the growth of $K$. marxianus $(1.6 \times 10$ $\mathrm{CFU} / \mathrm{mL}$ ) in a mixed culture. However when concentration of clove oil was brought down to $0.4 \%(\mathrm{v} / \mathrm{v})$ and was used in the fermented broth. C. krusei was inhibited at $0 \mathrm{~h}$ and $K$. marxianus $\left(1.7 \times 10^{7} \mathrm{CFU} / \mathrm{mL}\right)$ growth was unhampered at $6 \mathrm{~h}$ (Table 4). Clove oil $0.4 \%(\mathrm{v} / \mathrm{v})$ at similar set of $\mathrm{pH}$ and temperature used above was ideal for $C$. krusei inhibition in a mixed culture. Candida are associated with infections as they form biofilms, $S$. aromaticum extracts worked against biofilm formation and thus, inhibit the growth of C. krusei (Kim and Lee, 2012).

Table 4 The inhibition performed by using $0.4 \%(\mathrm{v} / \mathrm{v})$ of clove oil at $\mathrm{pH} 3.5$, $28^{\circ} \mathrm{C}$ in fermenter broth $(100 \mathrm{~mL})$

\begin{tabular}{ccc}
\hline $\begin{array}{c}\text { Time } \\
\text { (h) }\end{array}$ & \multicolumn{2}{c}{$\begin{array}{c}\text { Individual Organisms }\left(\log _{10} \text { CFU/mL) } \pm\right. \\
\text { Standard Deviation }\end{array}$} \\
& Ck & Km \\
\hline 0 & $7.21 \pm .03$ & $6.78 \pm .01$ \\
\hline 2 & NG & $6.91 \pm .01$ \\
\hline 4 & NG & $7.08 \pm .04$ \\
\hline 6 & NG & $7.26 \pm .03$ \\
\hline
\end{tabular}

Legend: NG- No Growth Observed, $\mathrm{Ck}-C$. krusei, $\mathrm{Km}-$ K. marxinaus

\section{Inhibition by nisin}

After $24 \mathrm{~h}$ of incubation the plates were observed and no yeast species were inhibited by nisin.

\section{Inhibition by $W$. saturnus}

A primary test was conducted to investigate the interaction between $W$. saturnus and $C$. krusei, along with $K$. marxianus. From the plate technique, it was concluded that $W$. saturnus could inhibit $C$. krusei but not $K$. marxianus. It is necessary to check whether $C$. krusei is an inducer for the production of the killer protein in $W$. saturnus or the latter naturally produces extracellular protein KT4561.

\section{Usage of W. saturnus lyophilized powder}

A minimum of $156 \mu \mathrm{g} / \mathrm{mL}$ of lyophilized protein in YEPD media is equivalent to $321.9 \mu \mathrm{g} / \mathrm{mL}$ of lyophilized protein in cheese whey needed for the inhibition of C. krusei (Table 5). W. saturnus did not show any effect below $\mathrm{pH} 4.5$ and it grows well at $25-45{ }^{\circ} \mathrm{C}$. Also W. saturnus grow well at $\mathrm{pH} 3.5$ but failed to produce killer protein at the same $\mathrm{pH}$. 
Table 5 The inhibition zone created by the minimum concentration of the killer protein along with varying concentration from the lyophilized supernatant from $W$. saturnus

\begin{tabular}{lccc}
\hline Media & $\begin{array}{c}\text { Lyophilized supernatant } \\
\text { concentration }(\mathbf{m g} / \mathbf{m L}) \text { of } \boldsymbol{W} . \\
\text { saturnus }\end{array}$ & $\begin{array}{c}\text { Protein concentration }(\boldsymbol{\mu g} / \mathbf{m L}) \text { of } \\
\text { killer protein }\end{array}$ & $\begin{array}{c}\text { Inhibition zone formed by killer } \\
\text { protein }(\mathbf{c m s})(\text { Average }+ \\
\text { Standard Deviation) }\end{array}$ \\
\hline Cheese whey & 500 & 321 & $1.81 \pm .03$ \\
\hline Synthetic media (YEPD) & 700 & 475 & $1.50 \pm .08$ \\
\cline { 2 - 4 } & 200 & 156 & $1.00 \pm .01$ \\
\cline { 2 - 4 } & 250 & 158 & $1.50 \pm .02$ \\
\cline { 2 - 4 } & 500 & 168 & $2.11 \pm .03$ \\
\hline
\end{tabular}

Inhibition by synergistic effect of $\mathrm{H}_{2} \mathrm{O}_{2}$ and lyophilized W. saturnus/ supernatant from $W$. saturnus

4000 ppm of $\mathrm{H}_{2} \mathrm{O}_{2}$ could inhibit the growth of C. krusei in the fermented broth (mono-culture) obtained from continuous aerated fermentation (Table 3); and 200 $\mathrm{mg} / \mathrm{mL}$ (killer protein concentration is $156 \mathrm{mg} / \mathrm{L}$ ) was the concentration of lyophilized powder needed for the inhibition of $C$. krusei (obtained from Table 5). A synergistic effect of $\mathrm{H}_{2} \mathrm{O}_{2}$ and lyophilized powder of W. saturnus was studied. The set of experiments conducted at $\mathrm{pH} 5.0$ and $40{ }^{\circ} \mathrm{C}$, where $4000 \mathrm{ppm}$ of $\mathrm{H}_{2} \mathrm{O}_{2}$ and $200 \mathrm{mg} / \mathrm{mL}$ of lyophilized $W$. saturnus powder was added. $W$. saturnus was highly effective in killing $C$. krusei, but in these set of experiments; such an inhibition did not occur because $W$. saturnus possesses peroxidase activity, which along with $K$. marxianus degraded $\mathrm{H}_{2} \mathrm{O}_{2}$ at a much faster rate than K. marxianus alone (Buzzini et al., 2004).

2400 ppm of $\mathrm{H}_{2} \mathrm{O}_{2}$ was considered along with $200 \mathrm{mg} / \mathrm{mL}$ of lyophilized supernatant of $W$. saturnus grown in cheese whey at $\mathrm{pH} 5.0$ and $40{ }^{\circ} \mathrm{C}$. At $24 \mathrm{~h}$, cell concentration of C. krusei was reduced (Figure 4). By increasing the concentration of lyophilized supernatant of $W$. saturnus to $300 \mathrm{mg} / \mathrm{mL}$, complete inhibition did not take place in a mixed culture. Simultaneously when $2400 \mathrm{ppm}$ $\mathrm{H}_{2} \mathrm{O}_{2}$ and $400 \mathrm{mg} / \mathrm{mL}$ of lyophilized supernatant of $W$. saturnus was applied, $\mathrm{H}_{2} \mathrm{O}_{2}$ was degraded between $0-6 \mathrm{~h}$ because of the catalase-peroxidase enzymatic activity from $K$. marxianus and $W$. saturnus, but lyophilized supernatant of $W$. saturnus showed activity till $24 \mathrm{~h}$. C. krusei $(\mathrm{CFU} / \mathrm{mL})$ lowered and showed drastic reduction in cell concentration at $24 \mathrm{~h}$, whereas $K$. marxianus $\left(1.8 \times 10^{7}\right.$ $\mathrm{CFU} / \mathrm{mL}$ ) remained unaffected.

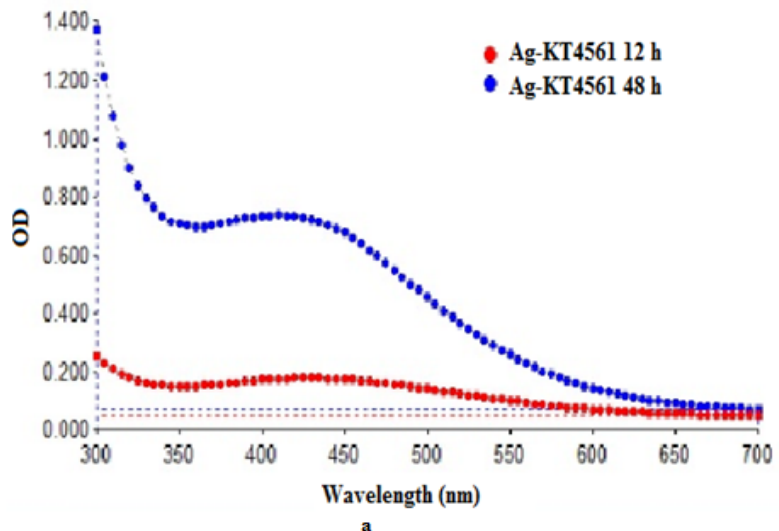

Figure 5 a) UV-VIS spectroscopy showed peak at $410 \mathrm{~nm}$ at $12 \mathrm{~h}$ and maximum at $48 \mathrm{~h}$ during bulk preparation of Ag-KT4561; b) A 12 h study of C. krusei when various concentrations of Ag-KT4561 was mixed with cheese whey
While growth curves of K. marxianus slightly decreases from $8.9 \times 10^{8}$ to $2.6 \times 10^{8}$ (Figure $5 \mathrm{~b}$ ). The decrease was less than a $\log$-unit and this might be due to the presence of silver in the Ag-NPs. The other concentrations of the Ag-KT4561 used are as less as $10 \mu \mathrm{M}$ and as maximum as $1 \mathrm{mM}$. In any food and feed grade products, a very high concentration of biomolecule based nanoparticle may be toxic for consumption but at a lower concentration of $350 \mu \mathrm{M}$ (with $1 \mathrm{ppm}$ of reduced silver ions), Ag-KT4561 is an efficient bio-preservative. Another effective approach to use biomolecule based nanoparticle is, no $\mathrm{pH}$ adjustment and no temperature adjustment is required. $\mathrm{Ag}^{0}$ has anti-microbial effects against a wide range of pathogenic microorganisms and since Ag-KT4561 is a

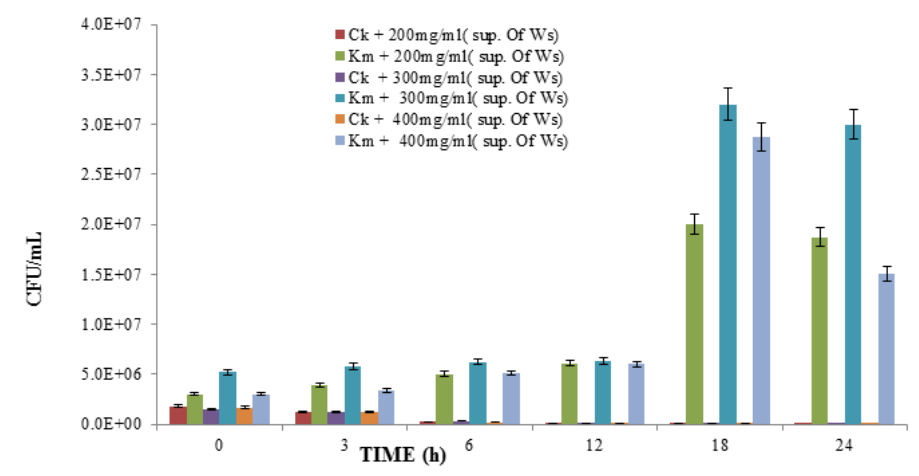

Figure 4 Impact of $2400 \mathrm{ppm} \mathrm{H}_{2} \mathrm{O}_{2}$ with $200-400 \mathrm{mg} / \mathrm{mL}(156-200 \mu \mathrm{g} / \mathrm{mL}$ killer protein) of lyophilized supernatant W. saturnus (Ws) powder on the mixed culture $(C$. krusei $(\mathrm{Ck})$ and $K$. marxianus $(\mathrm{Km}))$ in the fermenter broth at $\mathrm{pH} 5.0$ and $40{ }^{\circ} \mathrm{C}$ (Shake flask)

\section{Inhibition of $C$. krusei by Ag-KT4561 NPs}

Higher concentration of the Ag-KT4561 was observed at $48 \mathrm{~h}$ than at $12 \mathrm{~h}$ (Figure 5a). Therefore NPs formed at $48 \mathrm{~h}$ were considered for this study. A concluding study of the mixed culture (C. krusei and $K$. marxianus) along with silver-KT4561 nanoparticles (Ag-KT4561NP) at pH 5.5 and $30^{\circ} \mathrm{C}$ showed that $350 \mu \mathrm{M}$ of Ag-KT461 could efficiently inhibit $C$. krusei. At concentration of 350 $\mu \mathrm{M}$ (Ag-KT4561), the conjugate consists of $1 \mathrm{ppm}$ of reduced Ag.

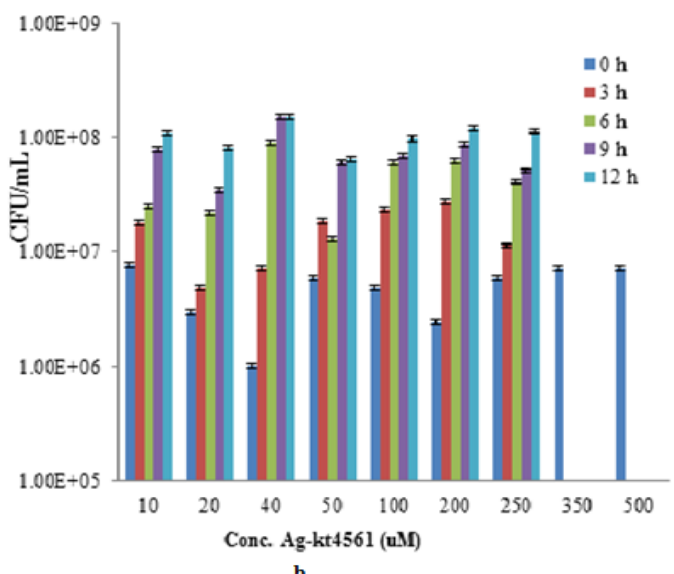

combination of killer protein from $W$. saturnus which specifically targets $C$. krusei. A synergistic effect of both (reduced $\mathrm{Ag}$ ion and killer protein) can kill $C$. kruse $i$ and $K$. marxianus remains partially affected (Figure 5b and 6a). A stability test of Ag-KT4561(350 uM) was performed on cheese whey till $12 \mathrm{~h}$ for 20 weeks and every time $C$. krusei was killed after being inoculated at $0 \mathrm{~h}$ and $K$. marxianus showed growth at a maximum of $2.3 \times 10^{8} \mathrm{CFU} / \mathrm{mL}$. Though $K$. marxianus growth was affected it did not perish away with the concentration of $\mathrm{Ag}$ in Ag-KT4561 (Figure 6b). A tabular representation (Table 6) shows the economics of bio-inhibitor (Ag-KT4561) production in a bulk amount of 20 , $000 \mathrm{~L}$ with a minimum of $1 \mathrm{ppm}$ reduced silver ions. 

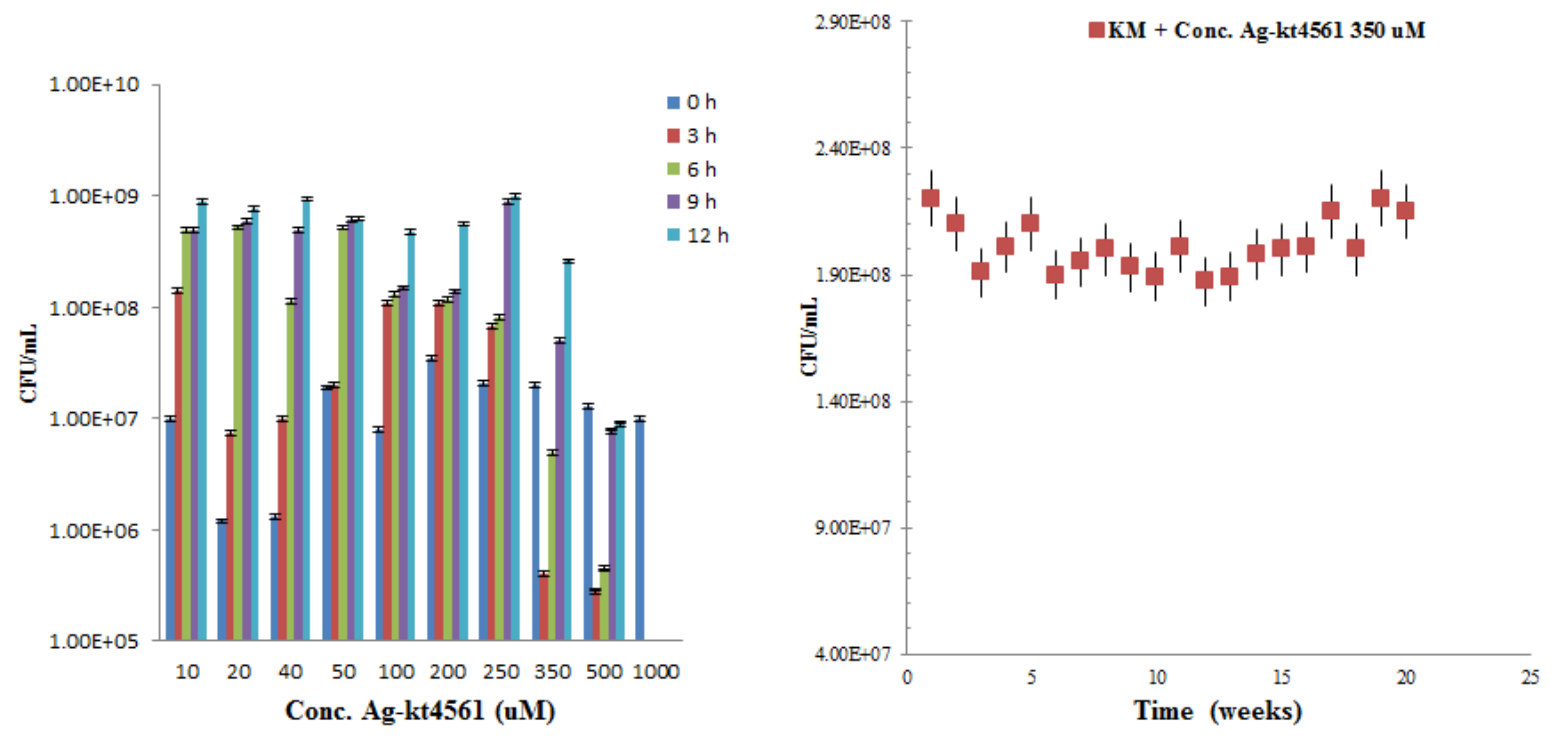

b

Figure 6 a) A 12 h study of $K$. marxianus when various concentrations of Ag-KT4561 was mixed with cheese whey; b) A stability test done for 20 weeks representing growth of $K$. marxianus $(\mathrm{KM})$ at a minimum of $2.1 \times 10^{8}$ and no traces of $C$. krusei

Table 6 Bio preservative (Ag-KT4561 conjugate) production of 20,000 L

\begin{tabular}{|c|c|c|}
\hline S. No & Items Required (amount) & $\begin{array}{l}\text { Cost of Production } \\
\text { (CAD \$) }\end{array}$ \\
\hline & Reagents and culture medium for stock & \\
\hline 1 & Silver nitrate $(271.6 \mathrm{~g})$ for $40 \mathrm{~L} \mathrm{~d} . \mathrm{H}_{2} 0$ & 242 \\
\hline 2 & $\begin{array}{l}\text { Culture medium of W. saturnus } 360 \mathrm{~L} \\
\text { Preparation cost }\end{array}$ & 306 \\
\hline 3 & $\begin{array}{l}\text { Mechanical stirring of } \mathrm{AgNO}_{3} \text { reagent }(36 \mathrm{~W} \\
\text { Input power) for } 48 \mathrm{~h}(\sim 1.728 \mathrm{kwh})\end{array}$ & 12.19 \\
\hline 4 & $\begin{array}{l}\text { Centrifugation (700W) for } 15 \text { mins }(\sim 0.175 \\
\text { kwh) }\end{array}$ & 1.23 \\
\hline \multirow[t]{2}{*}{5} & Freeze drying $(1200 \mathrm{~W})$ for $24 \mathrm{~h}(\sim 28 \mathrm{kwh})$ & 197 \\
\hline & Total & 760 \\
\hline 6 & $10 \%$ cost of man-power & 76 \\
\hline
\end{tabular}

\section{DISCUSSION}

The results indicated that $2 \mathrm{M} \mathrm{NaCl}$ could effectively inhibit $C$. krusei in a monoculture of $K$. marxianus at temperature $40^{\circ} \mathrm{C}$, pH 3.5 without affecting the growth of $K$. marxianus. However, C. krusei showed lower $\mathrm{NaCl}$ tolerance than any other yeast species e.g. Saccharomyces had different sensitivity towards osmotic stress, but $C$. krusei was inhibited efficiently at $2 \mathrm{M}$ without affecting the growth of $K$. marxianus (Lynum and Nauth, 2000; Uchida et al., 2005). The reported concentration is used to discriminate $K$. marxianus as it is sensitive up to a concentration of $3 \mathrm{M} \mathrm{NaCl}$. Stress-induced by salt induction results into two different phenomena, primarily, ion toxicity and secondly, osmotic stress. Apparently, other physiological changes can also take place such as: a) efflux of intracellular $\mathrm{H}_{2} \mathrm{O}$, i.e. total cell volume deduction; b) transient increase in glycolytic intermediates and finally triggering the hyper osmotic glycerol signaling pathway. Specific species, such as Saccharomyces and Klyuveromyces can develop systems to counteract to osmotic stress by $\mathrm{NaCl}$. Special features of Saccharomyces and Klyuveromyces species are that they produce intracellular trehalose under stress conditions to maintain the membrane integrity and stabilizing the proteins (Kuhn et al., 2004; Wang and Wu, 2008; Davey, 2011) However, in large-scale fermenters, it was not possible as it would lead to high utilization of $\mathrm{NaCl}$ for the inhibition of C. krusei. At industrial scale, such inhibitions performed by utilization of $\mathrm{NaCl}$ is difficult not because of the market price which is 16-20 USD per $\mathrm{Kg}$; but the volume of $\mathrm{NaCl}$ required was more than $500 \mathrm{Kg}$ for $40000 \mathrm{~L}$ industrial reactor (Goretti et al., 2009; Kosseva et al., 2009). Therefore, $\mathrm{NaCl}$ was not a suitable approach for $C$. krusei inhibition. Apparently, $\mathrm{H}_{2} \mathrm{O}_{2}$ was found to be effective at $300 \mathrm{ppm}$ when C. krusei inhibition was performed at shake flask level. In a shake flask study, it has been shown that 200 ppm could efficiently inhibit $C$. krusei (Nel et al., 2006). Other yeasts, such as $W$. saturnus and $K$. marxianus have shown no inhibition in the presence of $\mathrm{H}_{2} \mathrm{O}_{2}$ as both the yeasts showed catalase activity. Maximum oxidative stress was observed in case of Saccharomyces spp. which was nearly 2-folds more than $K$ marxianus (Kang et al., 2011). Every organism possesses specific antioxidantdefense systems. When $W$. saturnus was added along with $K$. marxianus and $C$. krusei, no inhibition of $C$. krusei was bound to happen as W. saturnus even possessed peroxidase activity (Buzzini et al., 2004). Apart from catalase, when $K$. marxianus was introduced to $\mathrm{H}_{2} \mathrm{O}_{2}$ in the exponential phase, other enzymes, such as superoxide dismutase and glutathione reductase content were even increased to 2 -fold (Nilsson, 2011). These were specific antioxidant defensive agents present in Klyuveromyces spp. (Meurman et al., 2007).

When $\mathrm{pH}$ was brought down from 6.0 to 3.5 , it did not affect the inhibition of $C$. krusei either. However, catalase was widely active in a vast range of $\mathrm{pH}(3.5-10)$ Apparently, decomposition of peroxidase lowered the $\mathrm{pH}$ in the medium (Pinto et al., 2009; Warnke et al., 2009; Guevara-Flores et al., 2010). While varying the $\mathrm{pH}$, temperature was increased to $40{ }^{\circ} \mathrm{C}$ and $\mathrm{C}$. krusei was efficiently inhibited. When it came to the effect of catalase activity on thermal capacity, 55 ${ }^{\circ} \mathrm{C}$ was the critical temperature and beyond which catalase enzyme was completely destroyed (Erdei et al., 2011). The factors that shifted the physiological process of the glutathione reductases in $K$. marxianus showed higher $\mathrm{pH}$ of 6.8 along with temperature $\left(37-40{ }^{\circ} \mathrm{C}\right)$ where it possesses more antioxidant activity (Ghaly et $\mathbf{a l . ,}$ 2005; Pinto et al., 2009).

In an aerated continuous fermenter, 4000 ppm of $\mathrm{H}_{2} \mathrm{O}_{2}$ was required without affecting the growth of $K$. marxianus and $W$. saturnus as both the microorganisms possessed catalase and peroxidase activity which efficiently degraded $\mathrm{H}_{2} \mathrm{O}_{2}$ during $6 \mathrm{~h}$ of inoculation. With such an extreme concentration of $4000 \mathrm{ppm}$ of $\mathrm{H}_{2} \mathrm{O}_{2}, K$. marxianus still had the capacity to resist it. However when fermenter conditions were considered, it was well-stated that $100 \mathrm{ppm}$ of $\mathrm{H}_{2} \mathrm{O}_{2}$ could cause corrosion of fermenter frame. The other catalysts for corrosion were $\mathrm{O}_{2}$ and higher temperature (Sathishkumar et al., 2010). Again, $\bullet \mathrm{OH}, \mathrm{H}_{2} \mathrm{O}_{2}$, $\mathrm{O}_{2}, \mathrm{H}_{2}, \cdot \mathrm{O}_{2}$ could interact with the surroundings; and therefore led to corrosive behavior of many materials including stainless steel (McMahon et al., 2007; Siddique and Wahid, 2012). Though, $\mathrm{H}_{2} \mathrm{O}_{2}$ might be an inexpensive ingredient for $C$. krusei inhibition, fermenter inner body could have corrosive effects. Therefore, lower concentration of $\mathrm{H}_{2} \mathrm{O}_{2}$ might be an ideal approach. The use of chemicals depends entirely on the form of free radicals being produced and the damage they may or may not have on the fermenter.

Simultaneously, it was observed that $0.45 \%$ (v/v) clove oil could inhibit $C$. kruse without affecting other yeasts. The factor responsible for inhibiting the growth of C. krusei was eugenol. Eugenol is the component present in clove oil which can kill C. krusei at optimum concentrations (Noori, 2012). S. aromaticum (clove oil) $0.4 \%$ (v/v) can efficiently bring down the concentration of C. krusei in a monoculture of $K$. marxianus. However, on a large-scale fermentation, it would not be an approachable or economical aspect for inhibition. When the prices were compared, it is observed that $200 \mathrm{Kg}$ of wholesale clove oil will cost USD 12 834.00, and definitely in large scale fermentations, the volume of clove oil required was $160 \mathrm{~L}$, which will not only make the final product oily, but also very expensive. Therefore, it was not an ideal approach for $C$. krusei using clove oil. Similarly when nisin was used for the inhibition as it is one of the biochemical approaches, nisin could not inhibit $C$. krusei at all. Henceforth, the focus was shifted to $W$. saturnus killer protein.

$W$. saturnus was found to be an effective species which could kill $C$. krusei in a mono-culture of $K$. marxianus without having any implications on $K$. marxianus. Killer protein produced by KT4561 at a concentration of $200 \mathrm{mg} / \mathrm{mL}$ (where killer protein concentration is $156 \mathrm{ug} / \mathrm{mL}$ ) when grown in glucose rich medium; 
and $400 \mathrm{mg} / \mathrm{mL}$ when grown in a lactose-efficient medium (cheese whey) can inhibit $C$. krusei. The purpose of production of lyophilized supernatant from $W$. saturnus is to justify that $W$. saturnus produces naturally occurring extracellular killer protein KT4561, which strongly inhibited $C$. krusei. The killer protein produced by $W$. saturnus caused cell membrane damage and an independent energy link in between the cell wall receptor and KT4561 at the region of $(1 \rightarrow 6)$ $\beta$-D-glucan complex (Fang et al., 2002).

More efficient inhibition of $C$. krusei was possible if $W$. saturnus would have been grown in a glucose-rich medium where efficient production of the killer protein could have inhibited $C$. krusei. This study revealed a real understanding of the different microbial species dealt with and different behavioral patterns with respective to the varied inhibitors used for the inhibition of $C$. krusei. The factor to be considered when biochemical approaches such as $\mathrm{H}_{2} \mathrm{O}_{2}$ were used is whether it again had any effect on the organic matter present in cheese whey. As over the years, approaches have been made to protect the food and humans from consuming it against any oxidative damage. Free radicals such as hydroxyl, peroxyl, and superoxide have been bound to release when biochemical methods are used for inhibiting the food pathogens (Erdemoglu et al., 2007).

Killer protein-based nanoparticle showed an effective inhibition for C. krusei. It was observed that $350 \mu \mathrm{M}$ of Ag-KT4561 (with $1 \mathrm{ppm}$ of Ag) could bring in effective inhibition of $C$. krusei within $3 \mathrm{~h}$. But beyond $350 \mu \mathrm{M}$ concentration could affect the growth $K$. marxianus. $K$. marxianus growth was affected due to the presence of $\mathrm{Ag}^{\mathrm{O}}$ but killer protein has no effect on it. Other significant consideration was that no $\mathrm{pH}$ or temperature was adjusted, because $\mathrm{Ag}$ ion was effective against almost all pathogens. Other benefit of using biomolecule based nanoparticle was that metal nanoparticles were toxic for human or animal consumption but biomolecule based nanoparticles had shown no toxicity so far (Nel et al., 2006; Da Silva et al., 2011).

\section{CONCLUSION}

Biomolecule based nanoparticle approach (Ag-KT4561) for inhibition of $C$. krusei served to be better method than other chemical and biochemical methods used in this study. Other suitable alternative approach might have been ultrafiltration, however, on an industry scale it was an expensive approach. Therefore, Ag-KT4561 was the effective and economic inhibitory approach towards $C$. krusei (non-Candida albicans spp.) and it even supported green chemistry. Although the composition of cheese whey was known, further verification and prolonged usage of killer protein-based silver nanoparticle to sustain the antimicrobial effect need to be investigated further.

Acknowledgements: The authors are sincerely thankful to the Natural Sciences and Engineering Research Council of Canada (Grant A4984, RDCPJ 379601, Canada Research Chair) for financial support. The views and opinions expressed in this article are strictly those of the authors.

\section{REFERENCES}

ADENIYI, C.B.A., ODUMOSU, B.T., AIYELAAGBE, O.O., KOLUDE, B. 2010. In-vitro antimicrobial activities of methanol extracts of Zanthoxylum xanthoxyloides and Pseudocedrela kotschyi. African Journal of Biomedical Research, 13(1), 61-68.

AGUIAR, C., LUCAS, C. 2000. Yeasts killer/sensitivity phenotypes and halotolerance. Food Technology and Biotechnology, 38(1), 39-46.

AHARIZ, M., COURTOIS, P. 2010. Candida albicans susceptibility to lactoperoxidase - generated hypoiodite. Clinical, Cosmetic and Investigational Dentistry, 2, 69-78. http://dx.doi.org/10.2147/cciden.s10891

AYOOLA, G.A., COKER, H.A.B., ADESEGUN, S.A., ADEPOJU-BELLO, A.A., OBAWEYA, K., EZENNIA, E.C., ATANGBAYILA, T.O. 2008 Phytochemical screening and antioxidant activities of some selected medicinal plants used for malaria therapy in southwestern Nigeria. Tropical Journal of Pharmaceutical Research, 7(3),

1019-1024. http://dx.doi.org/10.4314/tjpr.v7i3.14686

BHATTACHARYA, I., BEZAWADA, J., YAN, S., TYAGI, R.D. 2015 Optimization and production of silver-protein conjugate as growth inhibitor. $\begin{array}{llll}\text { Journal of } & \text { Bionanoscience, } & 9(4), & 261-269\end{array}$ http://dx.doi.org/10.1166/jbns.2015.1309

BROCK, M. 2008. Physiology and Metabolic Requirements of Pathogenic Fungi. The Mycota, 6(1), 63-82. http://dx.doi.org/10.1007/978-3-540-79307-6 4

BUZZINI, P., CORAZZI, L., TURCHETTI, B., BURATTA, M., MARTINI, A. 2004. Characterization of the invitro antimitotic activity of a novel killer protein from Williopsis saturnus DBVPG 4561 against emerging pathogenic yeasts FEMS Microbiology Letters, 238(2), 359-365. http://dx.doi.org/10.1111/i.15746968.2004.tb09777.x

CARVALHO, F., PRAZERES, A.R., RIVAS, J. 2013. Cheese whey wastewater: Characterization and treatment. Science of the Total Environment. 445-446: 385 396. http://dx.doi.org/10.1016/j.scitotenv.2012.12.038

CHEN, W.B., HAN, Y.F., JONG, S.C., CHANG, S.C. 2000. Isolation, purification, and characterization of a killer protein from Schwanniomyces occidentalis. Applied and Environmental Microbiology, 66(12), 5348-5352. http://dx.doi.org/10.1128/aem.66.12.5348-5352.2000

DA SILVA, B.F., PÉREZ, S., GARDINALLI, P., SINGHAL, R.K., MOZETO, A.A., BARCEIO, A. 2011. Analytical chemistry of metallic nanoparticles in natural environments. TrAC Trends in Analytical Chemistry. 30(3), 528-540. http://dx.doi.org/10.1016/j.trac.2011.01.008

DAVEY, H.M. 2011. Life, death, and in-between: meanings and methods in microbiology. Applied and Environmental Microbiology, 77(16), 5571-5576. http://dx.doi.org/10.1128/aem.00744-11

DE OLIVEIRA, B.P., LINS, C. C. d. S. A., DINIZ, F. A., MELO, L.L., DE CASTRO, C.M.M.B. 2014. In Vitro antimicrobial photoinactivation with methylene blue in different microorganisms. Brazilian Journal of Oral Sciences, 13(1), 53-57. http://dx.doi.org/10.1590/1677-3225v13n1a11

DINGMAN, J. 2008. Nanotechnology: It's Impact on food safety. Journal of Environment Health, 70(6), 47-50.

ERDEI, É., MOLNÁR, M., GYÉMÁNT, G., ANTAL, K., EMRI, T., PÓCSI, I., NAGY, J. 2011. Trehalose overproduction affects the stress tolerance of Kluyveromyces marxianus ambiguously. Bioresource Technology, 102(14), 7232-7235. http://dx.doi.org/10.1016/j.biortech.2011.04.080

ERDEMOGLU, N., OZKAN, S., TOSUN, F. 2007. Alkaloid profile and antimicrobial activity of Lupinus angustifolius L. alkaloid extract. Phytochemistry Reviews, 6(1),197-201. http://dx.doi.org/10.1007/s11101-0069055-8

EYSTER, H.C. 1950. Effect of temperature on catalase activity. Ohio Journal of Science, 50(6), 273-277.

FANG, Y.Z., YANG, S., WU, G. 2002. Free radicals, antioxidants, and nutrition. Nutrition, 18(10), 872-879. $\quad$ http://dx.doi.org/10.1016/ S08999007(02)00916-4

GHALY, A.E., KAMAL, M., CORREIA, L.R. 2005. Kinetic modeling of continuous submerged fermentation of cheese whey for single cell protein $\begin{array}{llll}\text { production. } \quad \text { Bioresource } & \text { Technology, 96, 1143-1152 }\end{array}$ http://dx.doi.org/10.1016/j.biortech.2004.09.027

GORETTI, M., TURCHETTI, B., BURATTA, M., BRANDA, E., CORAZZI, L., VAUGHAN-MARTINI, A., BUZZINI, P. 2009. In vitro antimycotic activity of a Williopsis saturnus killer protein against food spoilage yeasts. International journal of food microbiology, $131(2-3), \quad 178-182$ http://dx.doi.org/10.1016/j.ijfoodmicro.2009.02.013

GUEVARA-FLORES, A., ARENAL, I.P.D., MENDOZA-HERNÁNDEZ, G., PARDO, J.P., FLORES-HERRERA, O., RENDÓN, J.L. 2010. Mitochondrial thioredoxin-glutathione reductase from larval Taenia crassiceps (Cysticerci) $\begin{array}{llll}\text { Journal of Parasitology Research, 2010, 719-856. } & \end{array}$ http://dx.doi.org/10.1155/2010/719856

GUO, S., BHATTACHARJEE, J.K. 2006. Novel lysine biosynthetic gene sequences (LYS1 and LYS5) used as PCR targets for the detection of the pathogenic Candida yeast. Applied Microbiology and Biotechnology. 72(2), 416420. http://dx.doi.org/10.1007/s00253-006-0470-y

GUWY, A.J., MARTIN, S.R., HAWKES, F.R., HAWKES, D.L. 1999. Catalase activity measurements in suspended aerobic biomass and soil samples. Enzyme and Microbial Technology, 25, 669-676. http://dx.doi.org/10.1016/s0141 0229(99)00115-5

HEARD, G.M., FLEET, G.H. 1988. The effects of temperature and $\mathrm{pH}$ on the growth of yeast species during the fermentation of grape juice. Journal of Applied Bacteriology, 65, 23-28. http://dx.doi.org/10.1111/j.1365 2672.1988.tb04312.x

HORNBÆK，T., BROCKHOFF，P.B., SIEGUMFELDT, H., BUDDE，B.B. 2006. Two subpopulations of Listeria monocytogenes occur at subinhibitory concentrations of leucocin 4010 and nisin. Applied and Environmental Microbiology, 72, 1631-1638. http://dx.doi.org/10.1128/aem.72.2.1631 1638.2006

KANG, K., WONG, K.S., FONG, W.P., TSANG, P.W.K. 2011. Metergolineinduced cell death in Candida krusei. Fungal Biology, 115, 302-309. http://dx.doi.org/10.1016/i.funbio.2011.01.001

KAO, A.S., BRANDT, M.E., PRUITT, W.R., CONN, L.A., PERKINS, B.A., STEPHENS, D.S., BAUGHMANN, W.S., REINGOLD, A.L., ROTHROCK, G.A., PFALLER, M.A., PINNER, R.W., HAJJEH, R.A. 1999. The epidemiology of candidemia in two United States cities: results of a population-based active surveillance. Clinical Infectious Diseases, 29(5), 1164 1170. http://dx.doi.org/10.1086/313450

KIM, Y., LEE, H.S. 2012. Anticandidal effect of Syzygium aromaticum on biofilm formation, cell surface hydrophobicity, and cell cycle. Journal of Medicinal Plants Research, 6(10), 1926-1939.

KOLEVA, D.I., PETROVA, V.Y., KUJUMDZIEVA, A.V. 2008. Comparison of enzymatic antioxidant defense systems in different metabolic types of yeasts Canadian Journal of Microbiology. 54(11), 957-963. http://dx.doi.org/10.1139/w08-093

KOSSEVA, M.R., PANESAR, P.S., KAUR, G., KENNEDY, J.F. 2009. Use of immobilized biocatalysts in the processing of cheese whey. International Journal $\begin{array}{llll}\text { of Biological } & \text { Macromolecules, } & 45,\end{array}$ http://dx.doi.org/10.1016/j.ijbiomac.2009.09.005 
KUHN, D.M., MUKHERJEE, P.K., CLARK, T.A., PUJOL, C., CHANDRA, J., HAJJEH, R.A., WARNOCK, D.W., SOLL, D.R., GHANNOUM, M.A. 2004 Candida paralopsilosis characterization in an outbreak setting. Emerging Infectious Diseases, 10(6), 10741081. http://dx.doi.org/10.3201/eid1006.030873

LIU, H.J., LI, Q, LIU, D.H., ZHONG, J.J. 2006. Impact of hyperosmotic condition on cell physiology and metabolic flux distribution of Candida krusei. $\begin{array}{llll}\text { Biochemical Engineering Journal, 28(1), } & 92-98 .\end{array}$ http://dx.doi.org/10.1016/j.bej.2005.08.038

LOGOTHETIS, S., GRAEME, W., ELIAS, T.N. 2007. Effect of salt hyperosmotic stress on yeast cell viability. Zbornik Matice Srpske za Prirodne Nauke, 113, 271-284. http://dx.doi.org/10.2298/zmspn07132711

LOWES, K.F., SHEARMAN, C.A., PAYNE, J., MACKENZIE, D. ARCHER, D.B., MERRY, R.J., GASSON, M. J. 2000. Prevention of yeast spoilage in feed and food by the yeast mycocin HMK. Applied and Environmental Microbiology, 66(3), 1066-1076. http://dx.doi.org/10.1128/aem.66.3.1066-1076.2000

LOWRY, O.H., ROSEBROUGH, N.J., FARR, A.L., RANDALL, R.J. 1951. Protein measurement with the Folin Phenol reagent. Journal of Biological Chemistry, 193(1): 265-275.

LYNUM, M., NAUTH, K.R. 2000. Stabilization of cream cheese compositions using nisin-producing cultures. US Patent 6,110,509. Draft endorsed on 31 August.

MANEESRI, J., MASNIYOM, P. 2007. Induction and inhibition of film yeast from fermented bamboo shoot by seasoning plants. Songklanakarin. Journal of Science and Technology, 29(4), 1135-1143.

MANEESRI, J., MANEESRI, J. 2009. Effect of chemical factors and clove oil to decrease the growth of film yeast on fermented bamboo shoots. Asian Journal of Food and Agro-Industry. 2(4), 159-167.

MCMAHON, M.A.S., XU, J., MOORE, J.E., BLAIR, I.S., MCDOWELL, D.A. 2007. Environmental stress and antibiotic resistance in food-related pathogens. Applied and Environmental Microbiology, 73(1), 211-217. http://dx.doi.org/10.1128/aem.00578-06

MEURMAN, J.H., SIIKALA, E., RICHARDSON, M., RAUTEMAA, R. 2007 Non-Candida albicans Candida yeasts of the oral cavity. Applied Microbiology (Eds.), 719-731.

MORGULIS, S., BEBER, M., RABKIN, I. 1926. Studies on the effect of temperature on the catalase reaction. Journal of biological Chemistry, 68(3), 521 533.

NATHAN, P., LAW, E. J., MURPHY, D. F, MACMILLAN, B. G. 1978. A laboratory for the selection of topical antimicrobial agents. Burns, 4(3), 177-178 http://dx.doi.org/10.1016/s0305-4179(78)80006-0

NEL, A., XIA, T., MADLER, L., LI, N. 2006. Toxic potential of materials at the nanolevel. Science, 311, 622-627. http://dx.doi.org/10.1126/science.1114397 NILSSON, O. 2011. Radiation induced corrosion of steel. Thesis, Department of Chemistry, Nuclear chemistry: Royal Institute of Technology, 2011, 1-16p

NOORI, S. 2012. An overview of oxidative stress and antioxidant defensive system. Open Access Scientific Reports, 1(8), 1-9. http://dx.doi.org/10.4172/scientificreports.413

ORRUं, G., NERO, S.D., TUVERI, E., CIUSA, M.L., PILIA, F, ERRIU, M. ORRÙ, G., LICIARDI, G., PIRAS, V., DENOTTI, G. 2010. Evaluation of antimicrobial-antibiofilm activity of a hydrogen peroxide decontaminating system used in dental unit water lines. Open Dentistry Journal, 4, 140-146. http://dx.doi.org/10.2174/1874210601004010140

PANACEK, A., KOLAR, M., VECEROVA, R., PRUCEK, R., SOUKUPOVA, J., KRYSTOF, V., HAMAL, P., ZBORIL, R., KVITEK, L. 2009. Antifungal activity of silver nanoparticles against Candida spp. Biomaterials, 30, 63336340. http://dx.doi.org/10.1016/j.biomaterials.2009.07.065

PINHEIRO, R., ISABEL, B., MOTA, M. 2002. Oxidative stress response of Kluyveromyces marxianus to hydrogen peroxide, paraquat and pressure. Applied $\begin{array}{llll}\text { Microbiology and Biotechnology, 58(6), 842-847. } & \end{array}$ http://dx.doi.org/10.1007/s00253-001-0927-y

PINTO, E., VALE-SILVA, L., CAVALEIRO, C., SAlGUEIRO, L. 2009. Antifungal activity of the clove essential oil from Syzygium aromaticum on Candida, Aspergillus and dermatophyte species. Journal of Medical Microbiology. 58, 1454-1462. http://dx.doi.org/10.1099/jmm.0.010538-0

PRAZERES, A.R., CARVALHO, F., RIVAS, J. 2012. Cheese whey management: a review. Journal of Environmental Management, 110, 48-68. http://dx.doi.org/10.3923/jest.2012.155.167

RUSSELL, J.B., JARVIS, G.N. 2001. Practical mechanisms for interrupting the oral-fecal lifecycle of Escherichia coli. Journal of Molecular Microbiology and Biotechnology, 3(2), 265-272.

SATHISHKUMAR, T., SHANMUGAM, S., RAMESHKUMAR, S. RAJAVELAN, G., HARIDOSS, V. 2010. Characterization of salivary glutathione reductase in normal individuals and its implications on smokers. Researcher, 2(4), 74-81.

SIDDIQUE, N.I., WAHID, Z.A. 2012. Application of chemical and biologica coupled treatment technology in POME and petroleum waste water as biodegradation alternative. Journal of Environmental Science and Technology, 5(3), 155-167. http://dx.doi.org/10.3923/jest.2012.155.167
SISO, M.I.G. 1996. The biotechnological utilization of cheese whey: a review. Bioresource Technology, 57, 1-11. http://dx.doi.org/10.1016/09608524(96)00036-3

SOUZA, E.L.D., STAMFORD, T.L.M., LIMA, .E.D.O, FILHO, J.M.B, MARQUES, M.O.M. 2008. Interference of heating on the antimicrobial activity and chemical composition of Origanum vulgare L. (Lamiaceae) essential oil. Cienc Tecnol Aliment, 28(2), 418-422. http://dx.doi.org/10.1590/s010120612008000200023

UCHIDA, S., SHIGENAKA, N., TACHIBANA, M., WADA,Y., SAKAI, M., AKAMINE, K., OHSUMI, K. 1998. Effects of Hydrogen Peroxide on Intergranular Stress Corrosion Cracking of Stainless Steel in High Temperature Water, (I). Journal of Nuclear Science and Technology, 35(4), 301-308. http://dx.doi.org/10.1080/18811248.1998.9733860

WAEMA, S., MANEESRI, J., MASNIYOM, P. 2009. Isolation and identification of killer yeast from fermented vegetables. Asian Journal of Food and Agro-Industry, 2(4), 126-134

WALKER, G., DIJCK, P.V. 2006. Physiological and Molecular Responses of Yeasts to the Environment. Yeasts in Food and Beverages, 111-152. http://dx.doi.org/10.1007/978-3-540-28398-0 5

WALKER, L.A., MUNRO, C.A., BRUIJN, I.D., LENARDON, M.D., MCKINNON, A., GOW, N.A.R. 2008. Stimulation of chitin synthesis rescues Candida albicans from Echinocandins. PLoS Pathogens, 4(4), 1-12. http://dx.doi.org/10.1371/journal.ppat.1000040

WANG, J., WU, J. 2008. Antifungal activity of 25 -azalanosterol against Candida species. European Journal of Clinical Microbiology \& Infectious Diseases. 27(11), 1131-1136. http://dx.doi.org/10.1007/s10096-008-0554-y

WARNKE, P.H., BECKER, S.T., PODSCHUN, R., SIVANANTHAN, S. SPRINGER, I.N., RUSSO, P.A.J., WILTFANG, J., FICKENSCHER, H. SHERRY, E. 2009. The battle against multi-resistant strains: Renaissance of antimicrobial essential oils as a promising force to fight hospital-acquired infections. Journal of Cranio-Maxillofacial Surgery, 37(7), 392-397. http://dx.doi.org/10.1016/j.jcms.2009.03.017

YADAV, J.S.S., BEZAWADA, J., YAN, S., TYAGI, R.D., SURAMPALLI, R.Y. 2012. Candida krusei: biotechnological potentials and concerns about its safety. Canadian Journal of Microbiology, 58(8), 937-952. http://dx.doi.org/10.1139/w2012-077 